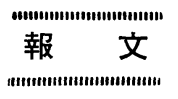

\title{
硫酸-セリウム $(\mathrm{IV})$ 溶液中における高クロム含有酸化物の 溶解挙動*
}

\author{
諏訪 武**, 栗林伸英**, 立川円造** \\ ** 日本原子力研究所東海研究所化学部
}

\author{
Dissolution Behavior of Chromium-rich Oxides in Sulfuric \\ Acid-Cerium (IV) Solution* \\ Takeshi Suwa**, Nobuhide Kuribayashi** and Enzo Tachikawa** \\ **Department of Chemistry, Tokai Research Establishment, \\ Japan Atomic Energy Research Institute
}

\begin{abstract}
The dissolution behavior of chromium-rich oxides in sulfuric acid-cerium (IV), SC, solution has been investigated in connection with developing a chemical decontamination process for nuclear facilities. Each dissolution rate of $\mathrm{Cr}, \mathrm{Ni}$, and $\mathrm{Fe}$ components in the oxide, $\mathrm{Cr}_{0.6} \mathrm{Ni}_{0.6} \mathrm{Fe}_{1.8} \mathrm{O}_{4}$, greatly depends on the redox potential and $\mathrm{pH}$ of the $\mathrm{SC}$ solution. The magnitude of their rates is in the following order: $\mathrm{Fe} \gg \mathrm{Ni}>\mathrm{Cr}=0$ in $0.25 \mathrm{M} \mathrm{H}_{2} \mathrm{SO}_{4}$ without $\mathrm{Ce}^{4+}$ and $\mathrm{Cr} \gg \mathrm{Ni}>\mathrm{Fe}$ in the $\mathrm{SC}$ solution, indicating that the rates of $\mathrm{Cr}$ and $\mathrm{Ni}$ increase in an oxidative solution. The rate of $\mathrm{Cr}$ is a first order dependence on $\mathrm{Ce}^{4+}$ concentration. The amount of $\mathrm{Ce}^{4+}$ required to dissolve the oxides can be calculated if the amount of the oxides and their components were known. Namely, the dissolution is governed by redox reactions, in which $\mathrm{Fe}$ (II) and $\mathrm{Cr}$ (III) in the oxides are completely oxidized to $\mathrm{Fe}$ (III) and $\mathrm{Cr}$ (VI), but $\mathrm{Ni}$ (II) and $\mathrm{Fe}$ (III) unchanged. The difference in the total dissolution fractions between in the $\mathrm{SC}$ and $\mathrm{HNO}_{3}-\mathrm{Ce}^{4+}$ solutions suggests that the ability of a decontamination solution to dissolve the oxides should be evaluated not only by their initial dissolution rates but also the total amount of the oxides dissolved.
\end{abstract}

\section{1. 緒言}

原子炉一次冷却系で発生する放射性腐食生成物（以下 クラッドと呼ぶ）を化学薬品を用いて溶解・除去する化 学除染法は, すでに欧米では稼動中の発電プラントに適 用されている1) 4)。また，寿命を終えた発電プラントの 解体 (デュミッショニング) のための化学除染技術の開 発も進められている4)。

これらのクラッドの性状は BWR と PWR により, また場所によっても大きく異なるが，一般に外層と呼ば れる付着性酸化物 (主として $\alpha-\mathrm{Fe}_{2} \mathrm{O}_{3}, \mathrm{Fe}_{3} \mathrm{O}_{4}, \mathrm{NiFe}_{2} \mathrm{O}_{4}$ ) と, 内層と呼ばれる成長性酸化物の二層から成ってい る。配管表面のクラッド組成は BWR では $\mathrm{Fe}(80$ 〜

\footnotetext{
* 日本原子力学会 $(1984$, 於日本原子力研究所 $)$ で 発表

** 产319-11 茨城県那珂郡東海村 (Tokai-mura, Ibaraki-ken, 319-11 Japan)
}

90\%)，PWR では Cr と Ni (60～80\%) の含有量が非常 に高い1。しかし炉型にかかわらず内層酸化物は母材 表面の腐食により生成することから，母材組成の影響を 強く受ける。ステンレス鋼やインコネル上の内層は, 腐 食により $\mathrm{Fe}$ は炉水中へ溶出し難溶性の $\mathrm{Cr}$ が濃縮さ れるため, $\mathrm{Cr}$ 含有量が高い。高 $\mathrm{Cr}$ 含有クラッド $(10$ 〜20\% 以上） に対する除染法では，酸化前処理段階で $\mathrm{Cr}(\mathrm{III})$ から水溶性の Cr (VI) に酸化溶解し，ひき続き 未溶解の $\mathrm{Fe}, \mathrm{Ni}$ を還元溶解するといら二段階処理が とられている1)。このために除染工程が複雑になり，除 染廃液量も増えるといら問題点がある。

著者らは, 一段階処理で高 $\mathrm{Cr}$ 含有クラッドを溶解す る除染法の開発を目的に各種模擬クラッドを用いて除染 剂の探索研究を行い, 硫酸一七リウム (IV) 溶液 (以下 $\mathrm{SC}$ 溶液と呼ぶ）が優れていることを見出した5)。 単一成分の金属酸化物の溶解挙動に関する研究は多数 
Table 1 Calculated values of cerium (IV) concentration required to dissolve oxide samples ${ }^{a}$.

\begin{tabular}{|c|c|c|c|c|c|}
\hline \multirow[b]{2}{*}{ Oxide } & article size & \multirow{2}{*}{$\begin{array}{c}M_{0}{ }^{c)} \\
\left(10^{-3} M\right)\end{array}$} & \multicolumn{3}{|c|}{$\mathrm{Ce}^{4+}$ concentration $\left(10^{-3} \mathrm{M}\right)$} \\
\hline & $(\mu \mathrm{m})$ & & $\mathrm{Cr}$ & $\mathrm{Fe}$ & $\mathrm{C}_{\mathrm{a}}$ \\
\hline $\mathrm{Cr}_{2} \mathrm{O}_{3}$ & 1.74 & 1.41 & 8.46 & - & 8.46 \\
\hline $\mathrm{CrFe}_{2} \mathrm{O}_{4}$ & 3.07 & 0.943 & 2.83 & 0.94 & 3.77 \\
\hline $\mathrm{Cr} 0.6{ }_{6} \mathrm{Ni}_{0.6} \mathrm{Fe}_{1.8} \mathrm{O}_{4}$ & 2.74 & 0.928 & 1.67 & 0.37 & 2.04 \\
\hline $\mathrm{CrNi}_{.} \mathrm{Fe}_{1.4} \mathrm{O}_{4}$ & 2.88 & 0.934 & 2.80 & 0.37 & 3.17 \\
\hline
\end{tabular}

a) Dissolution condition was $0.15 \mathrm{~g}$ of the oxide in $0.7 \mathrm{dm}^{3}$ solution.

b) Particle size as weight-average diameter

c) $M_{0}:$ Molar concentration

報告されているがあ)，多成分系の金属酸化物について， 各成分別の溶解挙動を検討した研究例は少ない、五。本報 では模擬クラッドとして JPDR 浄化系配管のクラッド 組成に近い $\mathrm{Cr}_{0.8} \mathrm{Ni}_{0.8} \mathrm{Fe}_{1.8} \mathrm{O}_{4}$ を取り上げら)，Cr を中心 飞各成分別の溶解挙動を検討した。さらに $\mathrm{Cr}$ 含有量の 異なる模擬クラッドを用い，溶解率と $\mathrm{Ce}^{4+}$ 消費量の関 係を検討した。

\section{2. 実験方法}

\section{1 試料及び試薬}

模擬クラッド試料は高純度化学製の $\mathrm{Cr}_{2} \mathrm{O}_{3}, \mathrm{CrFe}_{2} \mathrm{O}_{4}$ 及び $\mathrm{Cr}_{x} \mathrm{Ni}_{0.8} \mathrm{Fe}_{2.4-x} \mathrm{O}_{4}(x=0.6,1)$ の 4 種類で, 成分 比は SC 溶液で酸化処理した後, 塩酸で完全に溶解し, 発光分光分析装置（島津製作所製 ICPV-1000，以下 ICP と呼ぶ）により確認した。粒子径は ISOTONE II 電解液 (コールターエレクトロニクス社製の $0.85 \%$ $\mathrm{NaCl})$ 中で超音波処理を 5 分間行った後, 粒子径分布 測定装置 (コールター社製, コールターカウンタ TA-II 型）を用いて測定した (Table 1 参照)。

硫酸第 1 及び第 2 セりム $\left(\mathrm{Ce}_{2}\left(\mathrm{SO}_{4}\right)_{3}, \mathrm{Ce}\left(\mathrm{SO}_{4}\right)_{2}\right.$. $\left.n \mathrm{H}_{2} \mathrm{O}\right)$, 硝酸第 2 セリウム $\left(\left(\mathrm{NH}_{4}\right)_{2} \mathrm{Ce}\left(\mathrm{NO}_{3}\right)_{6}\right)$, 硫酸, 硝 酸等は全て試薬特級品をそのまま使用した。実験に用い た水は純水製造装置 (ミリポアリミテッド社製, MILLIQ）で製造した $0.1 \mu \mathrm{S} / \mathrm{cm}$ 以下のイオン交換水である。

\section{2 溶 解 試 験}

模擬クラッド $0.15 \mathrm{~g}$ と所定濃度の溶液 $0.7 \mathrm{dm}^{3}$ を 約 $1 \mathrm{dm}^{3}$ のガラス製セパラブルフラスコに入れ，ガラ ス製の攪拌羽根を用いて攪汼下で溶解した。所定時間ご とに溶液 $5 \times 10^{-3} \mathrm{dm}^{3}$ を採取し， $0.45 \mu \mathrm{m}$ のミリポア フィルタで沪過し，沪液中の溶出金属イオンをICP で 測定した。 $\mathrm{Ce}^{4+}$ 濃度は回転円板電極を用い還元電流量 から求めた ${ }^{8)}$ 。各試料の成分別溶解率 $f$ は次式から求め
た：

$$
f=C / C_{\infty}
$$

$C: t$ 時間後の溶液中の金属イオン濃度 (ppm)

$C_{\infty}: 100 \%$ 溶解した場合の計算値濃度 $(\mathrm{ppm})$

\section{3 溶解速度の解析法}

模擬クラッド武料を単分散の球形粒子とみなし, 溶解 反応は粒子表面で起こり, 溶解の進行につれて表面積が 縮少していくと仮定して導かれる次式を用いて, 溶解速 度を速度定数 $K\left(\mathrm{~h}^{-1}\right)$ として求めた ${ }^{7), 9,10) 。 ~}$

$$
1-(1-f)^{1 / 3}=K t
$$

反応動力学的研究を行う場合には, 溶解速度は系の状 態変化の小さい初期速度を用いるが，除染の場合には初 期速度よりむしろ全体の溶解率 $\left(f_{\mathrm{a}}\right)$ の方が重要とな る。ここでは $\mathrm{Cr}_{0.6} \mathrm{Ni}_{0.6} \mathrm{Fe}_{1.8} \mathrm{O}_{4}$ の $\mathrm{Cr}, \mathrm{Ni}, \mathrm{Fe}$ 各成分 の $\mathrm{K}$ にいて, 温度 $\left(40 \sim 90^{\circ} \mathrm{C}\right)$, 硫酸 $(0.125 \sim 0.5 \mathrm{M})$ 及び $\mathrm{Ce}^{4+}\left(0 \sim 10 \times 10^{-3} \mathrm{M}\right)$ 濃度, $\mathrm{pH}(0.5 \sim 1.5)$ 等 の反応条件による影響を検討した。

\section{4 セリウム (IV) 必要量の推定}

模擬クラッド試料を溶解するのに必要な $\mathrm{Ce}^{4+}$ 量をあ らかじめ予測するための計算を行った。C $\mathrm{Ce}^{4+}$ 必要量は 各試料成分のうち, $\mathrm{Fe}(\mathrm{II}) \rightarrow \mathrm{Fe}(\mathrm{III}), \mathrm{Cr}(\mathrm{III}) \rightarrow \mathrm{Cr}$ (VI) の酸化に消費されるものとし， Ni(II) と Fe(III) は関 与しないものと仮定した。

$\mathrm{Cr}_{x} \mathrm{Fe}_{3-x} \mathrm{O}_{4}$ (A) 及び $\mathrm{Cr}_{x} \mathrm{Ni}_{0.6} \mathrm{Fe}_{2.4-x} \mathrm{O}_{4}$ (B) の場 合, それぞれ $\mathrm{Fe}^{\mathrm{II} O} \cdot \mathrm{Cr}_{x}{ }^{\mathrm{III}} \mathrm{Fe}^{\mathrm{III}}{ }_{2-x} \mathrm{O}_{3}, \mathrm{Fe}^{\mathrm{II}}{ }_{0.4} \mathrm{Ni}^{\mathrm{II}}{ }_{0.6} \mathrm{O}$. $\mathrm{Cr}^{\mathrm{III}} \mathrm{Fe}^{\mathrm{III}} \mathrm{2}_{2-x} \mathrm{O}_{3}$ とすると, $\mathrm{Ce}^{4+}$ 必要量 $C_{a}\left(10^{-3} \mathrm{M}\right)$ は次式で表される。

$$
\begin{aligned}
& C_{a}=M_{0}(3 \times 1) \quad(\mathrm{A} \text { 試料 }) \\
& \left.C_{a}=M_{0}(3 \times 0.4) \quad \text { (B 試料 }\right)
\end{aligned}
$$

ここで $M_{0}$ は模擬クラッド試料の濃度 $\left(10^{-3} \mathrm{M}\right)$ であ る。Table 1 に, 2.2 の溶解条件に和ける $M_{0}$ と $\mathrm{Ce}^{4+}$ 必要量を示す。 $\mathrm{Ce}^{4+}$ 必要量は $\mathrm{Cr}, \mathrm{Fe}$ 各成分別及びこ 


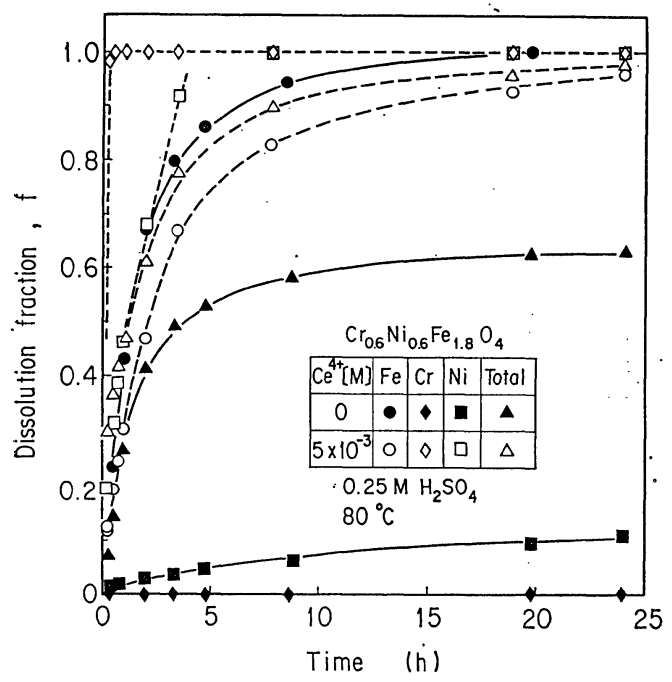

Fig. 1 Effect of the addition of $\mathrm{Ce}^{4+}$ on the dissolution behavior of $\mathrm{Cr}_{0.6} \mathrm{Ni}_{0.6} \mathrm{Fe}_{1.8} \mathrm{O}_{4}$ in $0.25 \mathrm{M} \mathrm{H}_{2} \mathrm{SO}_{4}$ solution.

れらの和 $\left(C_{a}\right)$ として示した。

\section{3. 実験結果及び考察}

\section{1 セリウム（IV）濃度の影響}

$\mathrm{Cr}_{0.6} \mathrm{Ni}_{0.6} \mathrm{Fe}_{1.8} \mathrm{O}_{4}$ の $0.25 \mathrm{M} \mathrm{H}_{2} \mathrm{SO}_{4}$ 単独及び $5 \times$ $10^{-3} \mathrm{M} \mathrm{Ce}^{4+}$ を含む溶液中に和ける各成分別及び全体の 溶解率の経時変化 (溶解曲線) を Fig. 1 亿示す。 $\mathrm{Ce}^{4+}=$ 0 の場合, 各成分別の溶解率は $f_{\mathrm{Fe}} \gg f_{\mathrm{Ni}}>f_{\mathrm{Cr}} \approx 0$ であ る。 $\mathrm{Ce}^{4+}=5 \times 10^{-3} \mathrm{M}$ の場合には， $f_{\mathrm{Cr}}>f_{\mathrm{Ni}} \gg f_{\mathrm{Fe}}$ とな り全く逆の傾向を示した。SC 溶液では Cr だけでなく $\mathrm{Ni}$ の溶解も大幅に促進されるため, 全体の溶解率は増 加した。ただし，Fe の溶解率は幾分低下した。

各成分の溶解速度定数は，(2) 式を用いて溶解曲線の データを再プロットし，反応初期（1〜2時間以内）の 直線部分の勾配から求めた。一例として $0.25 \mathrm{M} \mathrm{H}_{2} \mathrm{SO}_{4}$ $-5 \times 10^{-3} \mathrm{M} \mathrm{Ce} \mathrm{Ce}^{4+}$ 溶液で $40^{\circ} \mathrm{C}$ と $80^{\circ} \mathrm{C}$ の場合に拈け る $1-(1-f)^{1 / 2}$ vs. $t$ の関係を Fig. 2 に示す。

$\mathrm{Cr}, \mathrm{Ni}, \mathrm{Fe}$ 各成分の $K$ と $\mathrm{Ce}^{4+}$ 濃度の関係を Fig. 3 に示す。 $\mathrm{Cr}$ の溶解速度は $\mathrm{Ce}^{4+}$ 濃度の一次に比例し て増加するが, $\mathrm{Ni}$ の増加はわずかである。 Fe の溶解 速度は $\mathrm{Ce}^{4+}$ 無添加の場合に比べ, $\mathrm{Ce}^{4+}$ 存在下ではわ ずかに低下する傾向を示した。

\section{2 温度, 硫酸濃度及び pH の影響}

$\mathrm{Cr}_{0.6} \mathrm{Ni}_{0.6} \mathrm{Fe}_{1.8} \mathrm{O}_{4}$ の $0.25 \mathrm{M} \mathrm{H}_{2} \mathrm{SO}_{4}-5 \times 10^{-3} \mathrm{M} \mathrm{Ce}^{4+}$ 溶液中に扣ける $K$ の温度依存性をアレニウスプロット した結果を Fig. 4 に示す。 $\mathrm{Cr}, \mathrm{Ni}, \mathrm{Fe}$ 各成分とも温度 の上昇とともに溶解速度は増加する。これらの直線の勾 配から求めた見掛けの活性化エネルギーは, $\mathrm{Cr}, \mathrm{Ni}, \mathrm{Fe}$

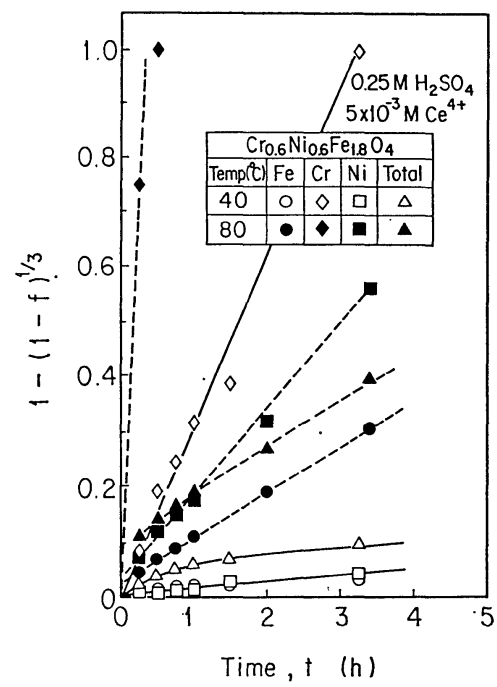

Fig. $21-(1-f)^{1 / 3}$ vs $t$ for the dissolution of $\mathrm{Cr}_{0.6} \mathrm{Ni}_{0.6} \mathrm{Fe}_{1.8} \mathrm{O}_{4}$.

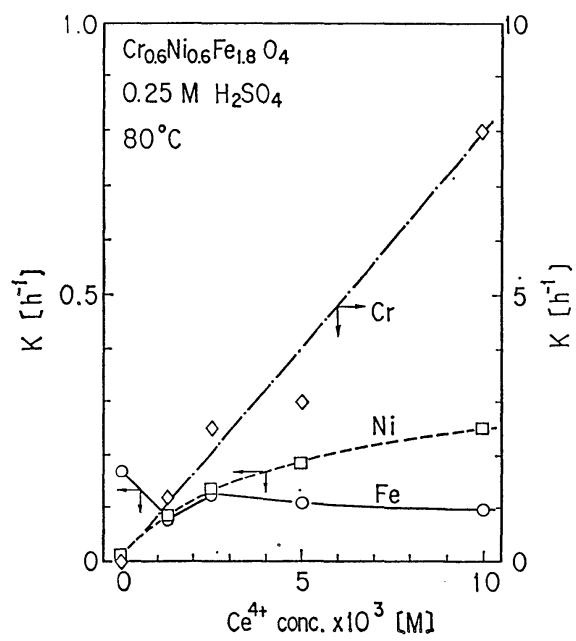

Fig. 3 Dissolution rate $K\left[\mathrm{~h}^{-1}\right]$ of $\mathrm{Cr}_{0.5} \mathrm{Ni}_{0.6} \mathrm{Fe}_{1.8^{-}}$ $\mathrm{O}_{4}$ as a function of $\mathrm{Ce}^{4+}$ concentration.

でそれぞれ 49, $55,44 \mathrm{~kJ} / \mathrm{mol}$ である。 $80^{\circ} \mathrm{C}$ に打いて $\mathrm{Cr}$ の溶解速度は $\mathrm{Ni}$ の約 20 倍, $\mathrm{Fe}$ の約 30 倍と非 常に大きい。

Fig. 5 には $\mathrm{Ce}^{4+}=5 \times 10^{-3} \mathrm{M}$ に拈ける $K$ と硫酸濃 度の関係を示す。Cr の溶解速度は硫酸濃度 $0.125 \mathrm{M}$ か ら $0.25 \mathrm{M}$ で急速に増加しているが， $0.25 \mathrm{M}$ 以上では 飽和する傾向を示す。 $\mathrm{Ni}$ と $\mathrm{Fe}$ の溶解速度はこの硫酸 濃度範囲では注とんど変化が見られない。さらに各組成 の溶解速度の $\mathrm{H}^{+}$濃度 $(\mathrm{pH})$ 依存性を明らかにするた めに実験した結果を Fig. 6 に示す。pH 調整は $\mathrm{NaOH}$ の添加により行った。溶解速度は $\mathrm{Cr}, \mathrm{Ni}, \mathrm{Fe}$ いずれも $\mathrm{pH}$ の増加と共に急速に低下した。 $\mathrm{d} \ln K / \mathrm{dpH}$ の概略 


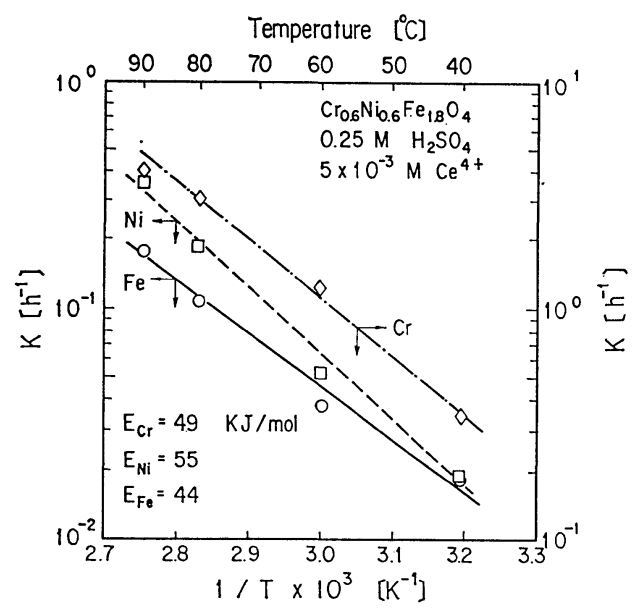

Fig. 4 Dissolution rate $K\left[\mathrm{~h}^{-1}\right]$ of $\mathrm{Cr}_{0.6} \mathrm{Ni}_{0.6} \mathrm{Fe}_{1.8^{-}}$ $\mathrm{O}_{4}$ as a function of temperature.

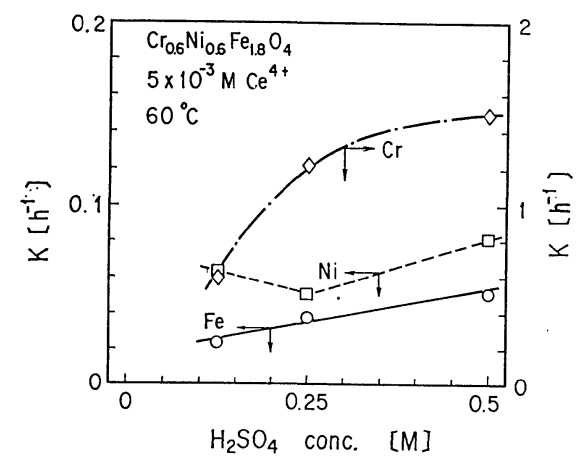

Fig. 5 Dissolution rate $K\left[\mathrm{~h}^{-1}\right]$ of $\mathrm{Cr}_{0.6} \mathrm{Ni}_{0.6} \mathrm{Fe}_{1.8^{-}}$ $\mathrm{O}_{4}$ as a function of $\mathrm{H}_{2} \mathrm{SO}_{4}$ concentration.

值は, $\mathrm{Cr}$ で $-1, \mathrm{Ni}$ と $\mathrm{Fe}$ で -0.5 である。すなわ ち溶解速度の $\mathrm{H}^{+}$濃度 $\left(C_{\mathrm{H}^{+}}\right)$依存性はそれぞれ $C_{\mathrm{H}^{+}}$ 及び $C_{\mathrm{H}^{+1 / 2}}$ である。

\section{3 還元剤の添加効果}

$\mathrm{SC}$ 溶液の電位 $E$ を $\mathrm{Ce}^{4+} / \mathrm{Ce}^{3+}=0.1 \sim 30(0.25 \mathrm{M}$ $\left.\mathrm{H}_{2} \mathrm{SO}_{4}, \mathrm{Ce}^{3+}+\mathrm{Ce}^{4+}=5 \times 10^{-3} \mathrm{M}\right)$ の範团で実測した結 果, ネルンストの式: $E=E^{0}+R T / n \mathrm{~F} \ln \mathrm{Ce}^{4+} / \mathrm{Ce}^{3+}$, と よく一致した。 $\mathrm{Ce}^{4+} / \mathrm{Ce}^{3+}=1$ に打ける標準電位 $E^{0}$ は $1.44 \mathrm{~V}$ (vs. NHE) であり文献值と一致しだ11。また $\mathrm{Ce}^{4+}=0$ 及び $5 \times 10^{-3} \mathrm{M}$ における電位はそれぞれ 0.79 及び $1.54 \mathrm{~V}$ であった。

Fig. 1 で明らかなように，溶液の電位 $(1.54 \mathrm{~V})$ が $\mathrm{Cr}$ の標準電位 $\left(\mathrm{Cr}(\mathrm{VI}) / \mathrm{Cr}(\mathrm{III}) \text { の } E^{0}=1.10 \mathrm{~V}\right)^{11)} よ$ り高くなると $\mathrm{Cr}$ と $\mathrm{Ni}$ で溶解速度は増加し, $\mathrm{Fe}$ で減 少する。そこで溶液の電位を $\mathrm{Fe}^{3+} / \mathrm{Fe}^{2+}$ の $E^{0}=$ $0.68 \mathrm{~V}^{11)}$ 以下にした場合どのような挙動を示すかを検 討するために, 還元剤としてアスコルビン酸を添加した

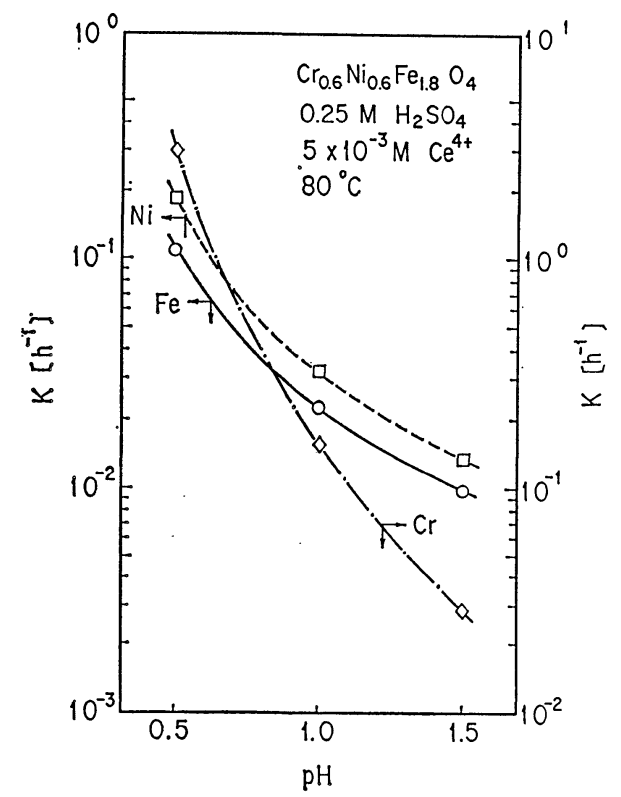

Fig. 6 Dissolution rate $\mathrm{K}\left[\mathrm{h}^{-1}\right]$ of $\mathrm{Cr}_{0.6} \mathrm{Ni}_{0.6} \mathrm{Fe}_{1.8^{-}}$ $\mathrm{O}_{4}$ as a function of $\mathrm{pH}$.

結果を Fig. 7 に示す。実線は還元剂を添加しない場 合，破線は Cr がほぼ 100\% 溶解した時点でアスコル ビン酸 ( $1 \mathrm{M}$ 溶液 $\left.3 \times 10^{-3} \mathrm{dm}^{3}\right)$ を添加した場合であ る。還元剤の添加により $\mathrm{Fe}$ の溶解は予測したと括り 促進されたが，Ni の溶解はほとんど進行しないといら 興味ある結果が得られた。アスコルビン酸を添加した時

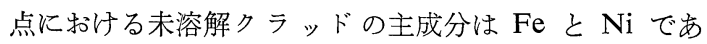
り, ニッケルフェライトに類似した酸化物であると推定 される。 $\mathrm{NiFe}_{2} \mathrm{O}_{4}$ の溶解速度はぎ酸バナジウム (II) / ピ コリン酸 (LOMI 除染剤, $\left.E^{0}=-0.41 \mathrm{~V}\right)$ のような還 元性溶液で大きくなることが Segal 等によって報告さ れている(10),12)。しかし，この溶解速度は Fe(III) から $\mathrm{Fe}(\mathrm{II})$ に還元することにより促進されると説明してお り，Ni についてはほとんど検討をしていない。Niの 溶解挙動については今後の検討課題であるが, Fig. 1 及 び Fig. 7 の結果から, $\mathrm{Cr}_{0.6} \mathrm{Ni}_{0.6} \mathrm{Fe}_{1.8} \mathrm{O}_{4}$ の溶解に拈い て Cr と Ni は酸化性溶液で, Fe は還元性溶液で溶解 速度は増大する。

\section{4 溶解に伴うセリウム (IV) の消費量}

クラッドの溶解によって消費される $\mathrm{Ce}^{4+}$ 量を把握す ることは, 除染の場合には重要となる。そこで, 2.4 で 述べた仮定の妥当性を検証するために, 実測した溶解率 から $\mathrm{Ce}^{4+}$ 消費量を計算し, この值が $\mathrm{Ce}^{4+}$ 濃度の実測 值とどの程度一致するかを比較した。溶液中の $\mathrm{Ce}^{4+}$ 濃 度は相対濃度 $C_{t} / C_{0}$ で示した。ここで $C_{0}$ は初期濃 度, $C_{t}$ は $t$ 時間後の濃度である。模擬クラッドとし ては $\mathrm{Cr}$ 単一成分の例として $\mathrm{Cr}_{2} \mathrm{O}_{3}, \mathrm{Cr}$ と $\mathrm{Fe}$ を含む 


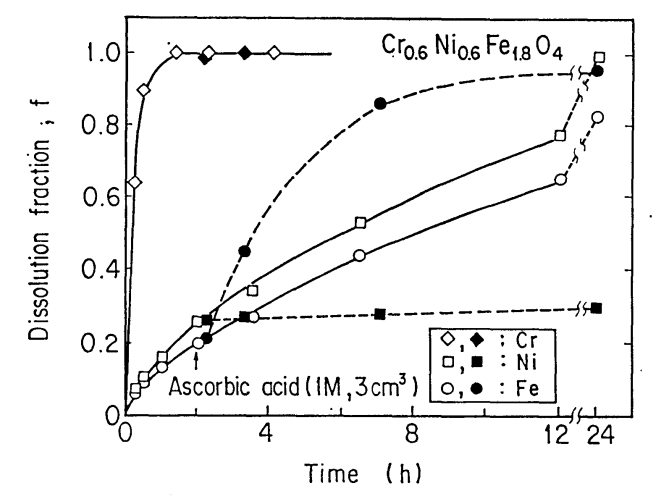

Fig. 7 Effect of the addition of ascorbic acid on the dissolution behavior of $\mathrm{Cr}_{0.8} \mathrm{Ni}_{0.8^{-}}$ $\mathrm{Fe}_{1.8} \mathrm{O}_{4}$ in $0.25 \mathrm{M} \mathrm{H}_{2} \mathrm{SO}_{4}-5 \times 10^{-3} \mathrm{M} \mathrm{Ce}^{4+}$ solution at $60^{\circ} \mathrm{C}$.

-: No addition; ---: Addition.

例として $\mathrm{CrFe}_{2} \mathrm{O}_{4}, \mathrm{Cr}, \mathrm{Ni}, \mathrm{Fe}$ を含むとして例 $\mathrm{Cr}_{0.6} \mathrm{Ni}_{0.6} \mathrm{Fe}_{1.8} \mathrm{O}_{4}$ と $\mathrm{CrNi}_{0.6} \mathrm{Fe}_{1.4} \mathrm{O}_{4}$ を選択し, これら の結果を Fig. 8 から Fig. 11 と示した。

Table 1 から, 上記 4 種類の模擬 クラッドの溶解に よる $C_{t} / C_{0}$ の計算值はとれぞれ次式で表される:

$C_{t} / C_{0}=\left(C_{0}-8.46 f_{\mathrm{Cr}}\right) / C_{0}$

$C_{t} / C_{0}=\left(C_{0}-2.83 f_{\mathrm{Cr}}-0.94 f_{\mathrm{Fe}}\right) / C_{0}$

$C_{t} / C_{0}=\left(C_{0}-1.67 f_{\mathrm{Cr}}-0.37 f_{\mathrm{Fe}}-0.56 f_{\mathrm{Ni}}\right) / C_{0}$

$C_{t} / C_{0}=\left(C_{0}-2.80 f_{\mathrm{Cr}}-0.37 f_{\mathrm{Fe}}-0.56 f_{\mathrm{Ni}}\right) / C_{0}$

ここで, $f_{\mathrm{Cr}}, f_{\mathrm{Fe}}, f_{\mathrm{Ni}}$ は所定時間ごとの実測值を用い た。図中 $C_{t} / C_{0}$ の計算曲線に执いて, A は $\mathrm{Cr}(\mathrm{III}) \rightarrow$ $\mathrm{Cr}(\mathrm{VI}), \mathrm{B}$ : $\mathrm{Cr}(\mathrm{III}) \rightarrow \mathrm{Cr}(\mathrm{VI}) \quad$ \& $\mathrm{Fe}(\mathrm{II}) \rightarrow \mathrm{Fe}(\mathrm{III}), \mathrm{C}$ はさらに $\mathrm{Ni}(\mathrm{II}) \rightarrow \mathrm{Ni}(\mathrm{III})$ となるものとして計算した場 合である。

$\mathrm{Cr}_{2} \mathrm{O}_{3}$ の溶解率と $C_{t} / C_{0}$ の経時変化を Fig. 8 に示 す。 $C_{t} / C_{0}$ は式 (5) 飞よる計算值と実測值で非常によ い一致が見られた。また， $\mathrm{Cr}_{2} \mathrm{O}_{3}$ の最終的な溶解率の実 測值 $f_{\text {obs }}$ は, $\mathrm{Ce}^{4+}$ 仕込及濃度 $C_{0}$ と $100 \%$ 溶解に必 要な $\mathrm{Ce}^{4+}$ 濃度 $C_{a}=8.46 \times 10^{-3} \mathrm{M}$ (Table 1) との比 から求めた計算值 $f_{\text {cal }}=C_{0} / C_{a}$ とほぼ一致する。例光ば, $C_{0}=5 \times 10^{-3} \mathrm{M}$ の場合, $f_{\mathrm{obs}}=0.62, f_{\mathrm{cal}}=0.59$ である。 $C_{0}=10 \times 10^{-3} \mathrm{M}$ の場合, $f_{\mathrm{obs}}=1$ であり, このとさの溶 液中の残存 $\mathrm{Ce}^{4+}$ 濃度は約 $2 \times 10^{-3} \mathrm{M}$ で, 消費された $\mathrm{Ce}^{4+} \approx 8 \times 10^{-3} \mathrm{M}$ であり， $C_{a}$ とほぼ一致した。

Fig. 9 から Fig. 11 と $\mathrm{CrFe}_{2} \mathrm{O}_{4}, \mathrm{Cr}_{0.8} \mathrm{Ni}_{0.6} \mathrm{Fe}_{1.8} \mathrm{O}_{4}$, 及び $\mathrm{CrNi}_{0.8} \mathrm{Fe}_{1.4} \mathrm{O}_{4}$ の溶解率と $C_{t} / C_{0}$ の経時変化を示 す。 $C_{t} / C_{0}$ の実測值と計算值曲線 $\mathrm{A}, \mathrm{B}, \mathrm{C}$ を比較する と, いずれの模擬クラッド試料棉いても実測值は曲線 B 近い。 $\mathrm{Ni}$ (II) $\rightarrow \mathrm{Ni}$ (III) と酸化されると仮定した曲

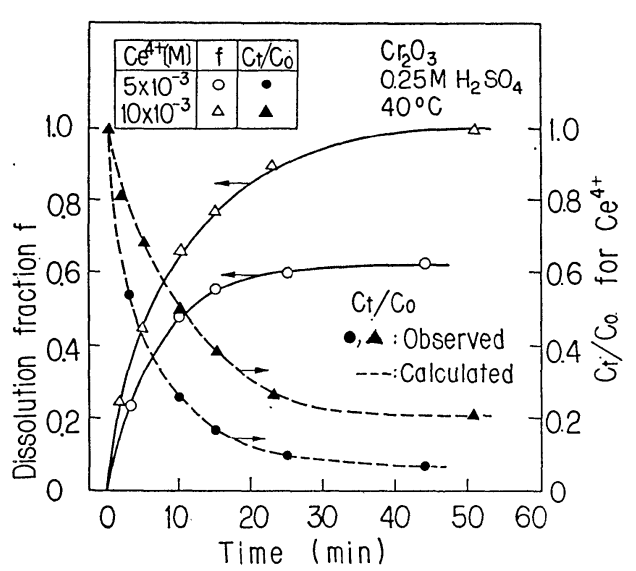

Fig. 8 Dissolution fraction of $\mathrm{Cr}_{2} \mathrm{O}_{3}$ and $C_{t} / C_{0}$ for relative concentration of $\mathrm{Ce}^{4+}$ as a function of time.

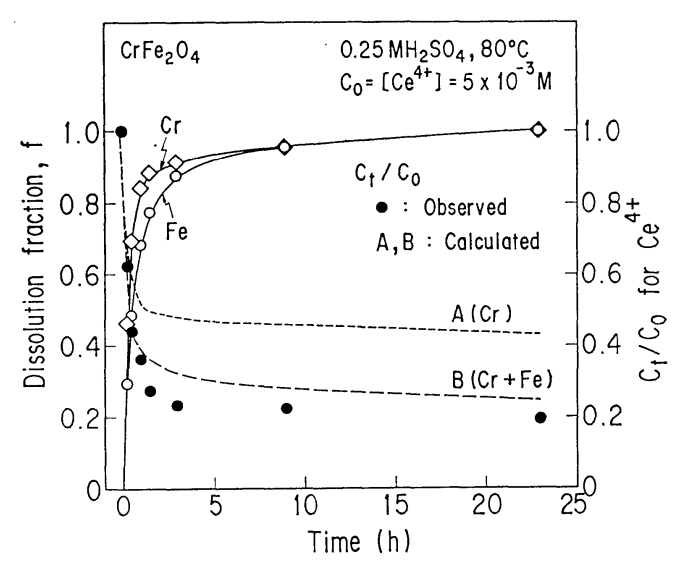

Fig. 9 Dissolution fraction of $\mathrm{CrFe}_{2} \mathrm{O}_{4}$ and $C_{t} / C_{0}$ for relative concentration of $\mathrm{Ce}^{4+}$ as a function of time.

線Cは実測值と大きくずれている。

これらの結果から模擬クラッドの溶解における $\mathrm{Ce}^{4+}$ 消費量は, 2.4 の仮定に基づくもの之考光られる。従っ て除染対象のクラッド量と形態及びその成分が明らかに なれば, クラッドの溶解に必要な $\mathrm{Ce}^{4+}$ 量は計算によっ て予測できる。

\section{5 各種模擬クラッドの溶解率と溶解速度}

Table 2 に, Fig. 8 から Fig. 11 飞示した模擬クラ ッドの 24 時間での溶解率 $\left(\mathrm{Cr}_{2} \mathrm{O}_{3}\right.$ は約 50 分）と溶解 速度を示す。試料別の全体の溶解速度の大きさは, $\mathrm{Cr}_{2} \mathrm{O}_{3}>\mathrm{CrNi}_{0.6} \mathrm{Fe}_{1.4} \mathrm{O}_{4}>\mathrm{CrFe}_{2} \mathrm{O}_{4}>\mathrm{Cr}_{0.6} \mathrm{Ni}_{0.8} \mathrm{Fe}_{1.8} \mathrm{O}_{4}$ である。Cr の溶解速度が最大であることから, 各試料 の金属成分中の $\mathrm{Cr}$ の占める割合の大きさとほぼ同一傾 向を示している。

$\mathrm{Cr}_{0.8} \mathrm{Ni}_{0.8} \mathrm{Fe}_{1.8} \mathrm{O}_{4}$ の溶解挙動については, 硫酸と硝酸 


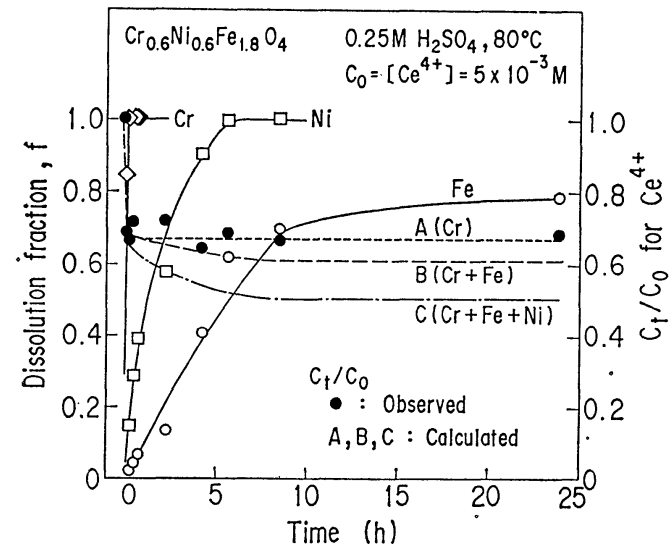

Fig. 10 Dissolution fraction of $\mathrm{Cr}_{0.6} \mathrm{Ni}_{0.8} \mathrm{Fe}_{1.8} \mathrm{O}_{4}$ and $C_{t} / C_{0}$ for relative concentration of $\mathrm{Ce}^{4+}$ as a function of time.

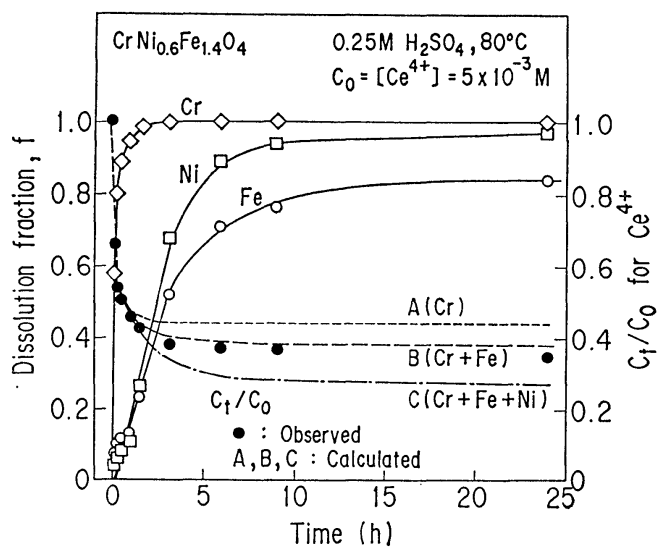

Fig. 11 Dissolution fraction of $\mathrm{CrNi}_{0.6} \mathrm{Fe}_{1.8} \mathrm{O}_{4}$ and $C_{t} / \mathrm{C}_{0}$ for relative concentration of $\mathrm{Ce}^{4+}$ as a function of time.

Table 2. Dissolution fractions and initial dissolution rates of metal oxides in $\mathrm{H}_{2} \mathrm{SO}_{4}-\mathrm{Ce}^{4+}$ solution.

\begin{tabular}{|c|c|c|c|c|c|c|c|c|c|c|c|}
\hline \multirow{3}{*}{ Oxide } & \multicolumn{3}{|c|}{ Dissolution condition } & \multirow{2}{*}{\multicolumn{4}{|c|}{$\begin{array}{l}\text { Dissolution fraction } \\
\text { at } 24 \mathrm{~h} \\
\end{array}$}} & \multirow{2}{*}{\multicolumn{4}{|c|}{$\begin{array}{l}\text { Initial dissolution } \\
\text { rate, } k\left(h^{-1}\right) \\
\end{array}$}} \\
\hline & $\mathrm{H}_{2} \mathrm{SO}_{4}$ & $\mathrm{Ce}^{4+}$ & & & & & & & & & \\
\hline & \multicolumn{2}{|c|}{$\left(10^{-3} \mathrm{M}\right)\left(10^{-3} \mathrm{M}\right)$} & $\left({ }^{\circ} \mathrm{C}\right)$ & $f_{C r}$ & $f_{\mathrm{Fe}}$ & $f_{N i}$ & $f_{a}^{a)}$ & $\mathrm{Cr}$ & $\mathrm{Fe}$ & $\mathrm{Ni} O$ & Overall \\
\hline \multirow[t]{4}{*}{$\mathrm{Cr}_{2} \mathrm{O}_{3}$} & 250 & 5 & 40 & 0.62 & - & - & 0.62 & 1.2 & - & - & 1.2 \\
\hline & 250 & 5 & 60 & 0.62 & - & - & 0.62 & 3.0 & - & - & 3.0 \\
\hline & 250 & 10 & 40 & 1.0 & - & - & 1.0 & 2.2 & - & - & 2.2 \\
\hline & 250 & 10 & 60 & 1.0 & - & - & 1.0 & 6.5 & - & - & 6.5 \\
\hline \multirow[t]{3}{*}{$\mathrm{CrFe}_{2} \mathrm{O}_{4}$} & 250 & 5 & 60 & 0.96 & 0.94 & - & 0.94 & 0.18 & 0.10 & - & 0.13 \\
\hline & 250 & 10 & 60 & 1.0 & 1.0 & - & 1.0 & 0.89 & 0.40 & - & 0.56 \\
\hline & 250 & 5 & 80 & 1.0 & 1.0 & - & 1.0 & 0.74 & 0.39 & - & 0.51 \\
\hline$B-1$ & 250 & 5 & 80 & 1.0 & 0.84 & 0.97 & 0.92 & 2.5 & 0.24 & 0.12 & 0.36 \\
\hline \multirow[t]{4}{*}{$B-2$} & 250 & 0 & 80 & 0 & 1.0 & 0.11 & 0.62 & 0 & 0.17 & $<0.01$ & 0.08 \\
\hline & 250 & 5 & 80 & 1.0 & 0.96 & 1.0 & 0.98 & 2.0 & 0.11 & 0.18 & 0.17 \\
\hline & $500^{b)}$ & 0 & 80 & 0 & 0.67 & 0.08 & 0.42 & 0 & 0.02 & $<0.01$ & 0.01 \\
\hline & $500^{\mathrm{b})}$ & 5 & 80 & 0.86 & 0.55 & 1.0 & 0.70 & 4.0 & 0.03 & 0.82 & 0.16 \\
\hline
\end{tabular}

a) $f_{a}$ is overall dissolution fraction: b) $\| N O_{3}$ solution

B-1: CrNie. $6 \mathrm{Fe}_{1.4} \mathrm{O}_{4} ; \mathrm{B}-2: \mathrm{Cr}$. $6 \mathrm{Ni} 0.6 \mathrm{Fe}_{1 .} \mathrm{O}_{4}$

溶液中で比較した。 $\mathrm{Ce}^{4+}=0$ の場合, $\mathrm{Cr}$ と $\mathrm{Ni}$ の溶解 率及び溶解速度は両溶液中とも $\mathrm{Ce}^{4+}$ 存在下に比較して 非常に小さいが， $\mathrm{Fe}$ に関しては $\mathrm{Ce}^{4+}$ の存在の有無に よる影響は少ない。 $\mathrm{Ce}^{4+}=5 \times 10^{-3} \mathrm{M}$ 溶液の場合には， 全体の溶解速度は $\mathrm{SC}$ 溶液と $\mathrm{HNO}_{3}-\mathrm{Ce}^{4+}(\mathrm{NC})$ 溶液 ともほ汴同じであるのに対し，24 時間での全体の溶解
率は 0.98 と 0.70 で $\mathrm{SC}$ 溶液の方が大きい。この不一 致の原因は,

i) $\mathrm{Cr}$ と $\mathrm{Fe}$ の溶解挙動,

ii) $\mathrm{SC}$ とC 溶液中の $\mathrm{Ce}^{4+}$ の安定性,

の違いに起因するものと考光られる。i) については，特 に Fe の溶解率が NC 溶液で小さいために全体の溶解 
率を低下させている。これは両溶液の電位と関連してお り, $E^{0}$ は $\mathrm{SC}$ 溶液の $1.44 \mathrm{~V}$ に対し, $\mathrm{NC}$ 溶液では $1.62 \mathrm{~V}^{11)}$ と高い。従って $\mathrm{Cr}$ と $\mathrm{Ni}$ の溶解速度は電位 の高い NC 溶液で大きくなっているが，逆に Fe の溶 解速度は SC 溶液で大きくなっている。また， ii) につ いては, SC 溶液に比べ $\mathrm{NC}$ 溶液中での $\mathrm{Ce}^{4+}$ は不安 定で一部水と反応して $\mathrm{Ce}^{3+}$ に還元される。

以上の結果から除染剤の溶解性能を評価する場合, 試 料全体の初期溶解速度だけから判断するのは危険であ り，一定時間後に打忷る全体の溶解率の大きさ，さらに は溶液中の酸化剂の安定性等を考慮して総合的に評価す ることが重要である。

\section{4. 結 論}

硫酸一セリウム (IV) 溶液を除染剤として用いる除染 法の確立を計るために, 最も基本的なクラッドの溶解挙 動について, $\mathrm{Cr}, \mathrm{Ni}, \mathrm{Fe} 3$ 成分系の金属酸化物を用い て種々の条件下で検討し，以下の結論を得た。

1) $\mathrm{Cr}_{0.6} \mathrm{Ni}_{0.6} \mathrm{Fe}_{1.8} \mathrm{O}_{4}$ の各成分別の溶解率の経時変化 を測定し，各成分の溶解速度の $\mathrm{Ce}^{4+}$ 濃度，温度，硫酸 濃度及び $\mathrm{pH}$ 依存性を明らかにした。酸化剂である $\mathrm{Ce}^{4+}$ 無添加系では $\mathrm{Fe} \gg \mathrm{Ni}>\mathrm{Cr} \approx 0$ であるのに対し, $\mathrm{Ce}^{4+}$ 添加系では $\mathrm{Cr} \gg \mathrm{Ni}>\mathrm{Fe}$ となり, $\mathrm{Cr}$ と $\mathrm{Ni}$ の溶 解が促進される。Cr の溶解速度は $\mathrm{Ce}^{4+}$ 濃度の一次に 比例し, $\mathrm{Ni}$ の約 20 倍, $\mathrm{Fe}$ の約 30 倍と非常に大きい。

2) 酸化剂 $\left(\mathrm{Ce}^{4+}\right)$ 及び還元剤（アスコルビン酸）の 添加効果から， Cr と Ni は酸化性溶液で, Fe は還元 性溶液で溶解が促進される。

3）金属酸化物の溶解によって消費される $\mathrm{Ce}^{4+}$ 量 は, 酸化物成分中の $\mathrm{Cr}(\mathrm{III})$ から $\mathrm{Cr}(\mathrm{VI})$ 及び $\mathrm{Fe}(\mathrm{II})$ から Fe(III) に酸化するのに必要な量であり, Ni(II) と $\mathrm{Fe}(\mathrm{IIII})$ はほとんど関与しない。
4) $\mathrm{Cr}_{2} \mathrm{O}_{3}$ において, 実測の溶解率は $\mathrm{Ce}^{4+}$ 必要量の 計算值 $C_{a}$ と仕込及濃度 $C_{0}$ の比から求めた計算值 $f_{\mathrm{c} a 1}=C_{0} / C_{a}$ とほぼ一致する。すなわち溶解に関して酸 化還元当量が成立する。

5）模擬クラッドの各成分別の溶解挙動の検討から, 全体の初期溶解速度だけから除染剤の溶解性能を評価す るのは危険であり，全体の溶解率等を考慮することが重 要である。

(Received August 14, 1986)

\section{文献}

1)諏訪 武，安中秀雄：防食技術，32, 721 (1983).

2) ANS Executive Conf.: "Decontamination of Power Reactors: The Cost, Benefits and Consequences", Springfield, MA (1984).

3) 諏訪 武: 原子力工業, 31 [3] 21 (1985).

4）立川円造，諏訪 武，栗林伸英：原子力誌，28, 390 (1986).

5) T. Suwa, N. Kuribayashi, E. Tachikawa: $J$. Nucl. Sci. Technol., 28, 390 (1986).

6) J. W. Diggle: "Dissolution of Oxides Phases, Oxides and Oxide Films," Vol. 2, Ed. by J. W. Diggle \& Marcell Dekker, Inc., New York (1973).

7) A. E. Regazzoni \& E. Matijevic': Corrosion, 40, 257 (1984).

8）諏訪 武，栗林伸英，吉田善行，立川円造：電 気化学，54，974 (1986)

9）日本化学会編：“化学総説，No.9, 固体の関与す る無機反応”, p. 214 (1975).

10) M. G. Segal \& R. M. Sellers: J. Chem. Soc. Faraday Trans. 1, 78, 1149 (1982).

11）大木道則，田中元治編：“現代化学 9, 酸塩基と 酸化還元”, p. 191, 岩波書店 (1979).

12) R. A. Shaw: "Development of LOMI Chemical Decontamination Technology," EPRI NP-3177 (1983). 